\title{
The Effect of Advance Organizers on Enhancing the Reading Comprehension of Iranian EFL Learners
}

\author{
Rezvan Davaei \\ Islamic Azad University, Shahreza Branch, Isfahan, Iran \\ Email: Rezvan_davaie123@yahoo.com \\ Mohammad Reza Talebinezhad \\ Islamic Azad University, Shahreza Branch, Isfahan, Iran \\ Email: talebinejad@iaush.ac.ir
}

\begin{abstract}
Reading English in Iran is regarded as a very important skill in academic world, where English is learned as a foreign language (EFL). Therefore, the main purpose of this study was to examine the influence of Advance Organizers (AO) on enhancing reading comprehension of students of English as a foreign language to check if there is any correspondence between activating background knowledge and listening- whilereading tasks as two AOs for enhancing reading comprehension. To carry out this study, three intact classes consisting of 58 intermediate students studying English in Atiehsazan English Institute in Dehaghan, Isfahan, Iran were selected. Each intact class was randomly divided into two experimental groups including (1) background knowledge questioning; (2) listening-while-reading; and one control group. Background knowledge activation strategy was taught, based on CALLA instructional model, developed by Chamot \& O'Malley (1994). Results showed an increase in students' performance in reading comprehension due to the effect of background knowledge activation strategy and listening-while-reading task. In addition, the results also indicated that activating the students' background knowledge about the topic they are reading can significantly better enhance the learners' reading comprehension than forcing students to listen while they are reading simultaneously. These findings have a profound implication for instructional design, particularly because this research study targeted English language learners who have not mastered the English language fully, therefore, instructing them in the use and monitoring of reading strategies is an effective practice.
\end{abstract}

Index Terms—background knowledge, formal schemata, advance organizers (AOs), EFL

\section{INTRODUCTION}

In the last three decades, according to Horwitz (1987), there has been a shift in focus in the field of second language acquisition (SLA) from teaching methods to learner characteristics. He points out that it has become clearer that much of the responsibility for success in language learning may rest with the efforts of individual learners. learner's beliefs can play a role in bringing about this change. Further, particular sets of techniques and strategies are that individual learners use to learn a target language also significant in this change (Oxford, 1990). Rigney (1987) defined strategies operations or steps used by a learner to facilitate the acquisition, storage, or retrieval of information.

On the other hand, according to Karbalaei and Rajyashree (2009) teaching reading skills has been a foundation of adult-level EFL reading for at least the last two decades. In more recent years, skilled-based instruction has become increasingly popular in higher-level English as a foreign language (EFL) context as well, due to the attention it has received in EFL contexts. According to him, while in a general sense reading skills may refer to a variety of things including word-recognition and other "bottom-up" decoding skills, beyond the beginning levels the focus tends to have been on "top-down" or meaning-focused strategies which proficient readers have been found to employ in numerous second language (L2) descriptive studies.

On the other hand, in recent years, there has been a growing interest in general research on the mental images, thoughts, and processes L2/FL learners and teachers utilize during teaching or learning, respectively. It is believed that mental processes provide "interpretation frames which both groups use to understand and approach their own learning and teaching" (Richards, 1996, p.1).

As far as using skills and strategies for better reading comprehension is concerned, a body of research from the perspective of schema theory has shown how readers' perspectives and prior knowledge are important in comprehending and remembering what they read. Anderson and his colleagues (Anderson, 1978; Anderson \& Pearson, 1984; Anderson, Reynolds, Schallert, \& Goetz, 1977).For example, Bransford and Johnson (1972) came to this conclusion that readers' background knowledge and the previews suggested for readers, as well as the titles selected for 
ambiguous passages can have an influence not only on remembering information by readers but also on what they can comprehend from the written text.

Previous exposure and knowledge to new concepts may help to improve readingcomprehension and subsequently performance on recognition tasks (Rinehart et al., 1991). Advance organizers (AO), or "introductory material"that "bridges the gap between what the learner already knows and what he needs to knowbefore he can successfully learn the task at hand" (Ausubel, 1977, p. 168), are common methods for affording this exposure to individuals. Guided discussion is also effective inhelping individuals acquire this prior knowledge (Rinehart \& Welker, 1992).

During the past years, researchers have done a lot of studies regarding Advance Organizers; however, few studies have researched the effects of AOs in enhancing the reading performance of EFL learners. Since a brief, general discussion might be effective in improving exam scores, considerations for its use along with AOs seemsplausible. Therefore, the purpose of the present study was to examine the influence of Advance Organizers (AO) on enhancing reading comprehension of students of English as a foreign language to check if there is any correspondence between activating background knowledge and listening- while- reading tasks as two AOs for enhancing reading comprehension.

\section{A. Roles of Schemata in Comprehension}

A schema (plural schemata) is defined as a knowledge framework that represents a class of things, events and situations (Anderson, 1978, as cited in Song, 2011). A reader's understanding can be improved when a schema provides a kind of framework, which is interpretable and assists learners interpret data, retrieve information from memory, and determine goals and sub goals (Anderson \& Pearson, 1984; Rumelhart, 1981). For example, Rumelhart (1981) puts an emphasis on the importance of schemata by recognizing three reasons that readers might not be able to comprehend a passage correctly. First, readers do not possess correct schemata. Second, a text cannot be fully understood if the clues in the passage are not enough to activate the readers' schemata. Finally, at the same time, however, if readers bring schemata to their reading that are not the ones the author intended, they will have a problem understanding the passage.

Furthermore, schemata can pave the way for understanding. The way readers understand a passage hinges on what kind of information they have. Readers who have correct schemata about the reading material can easily connect between what they are reading and what they know. Therefore, schema specialists argue that a reader's schema can provide a framework for interpreting the discourse available to them, and that schema theory can explain how familiar situations are easily understood more (Anderson, Wang, \& Gaffney, 2006; Freebody \& Anderson, 1983).

In conclusion, according to Anderson (1994), schemata are essential for discourse comprehension because the processes of activating schemata that gives a good account for events in a text can play a significant role in understanding discourse.

\section{B. Purposes of the Study}

During the past years, the researcher has encountered some beginners of English who are interested in adding a new variety in their life by learning English as their foreign language because they believe that they can communicate with people around the world if they learn English. Among them, most of them have experienced learning English at guidance or high school but their improvement has been insignificant However, the majority of the beginners of English,in the case of EFL context, where the researcher taught English, had little previous experience of L2 learning. The fact is that, unfortunately, they have not started to learn the new language systematically during these years. By considering the above mentioned points, it is particularly challenging for the teacher to keep their learners engaged and motivated in the process of L2 learning.

The first issue which is taken into account in this study is examining the skills or strategies that learners apply in their learning. Of course, we should know that because different learners have different ideas for learning, we cannot achieve to a consensus in reporting the strategies or skills used by all learners.

Therefore, the main purposes of this study were to examine the influence of Advance Organizers (AO) on enhancing reading comprehension of students of English as a foreign language to check if there is any correspondence between activating background knowledge and listening- while- reading tasks as two AOs for enhancing reading comprehension.

\section{Research Questions}

Referring to the primary objectives of the study, the main research questions raised here are interrelated as follows:

1. Does activating background knowledge as a pre-reading task have any impact on EFL learners' reading comprehension performance?

2. Does listening-while-reading task have any impact on the learners' reading comprehension performance?

3. Is there any significant difference between the effect of background knowledge activation task and listening-whilereading task on reading comprehension?

\section{Research Hypothesis}

To investigate the above research questions of the present study, the following hypothesis are addressed:

1. Activating background knowledge as a pre-reading task can have an influence on Iranian EFL students' performance in reading comprehension. 
2. Listening-while-reading task can have an influence on Iranian EFL students' performance in reading comprehension.

3. There is no significant difference between the effect of background knowledge activation task and listening-whilereading task on reading comprehension.

\section{METHOD}

\section{A. Participants}

The participants in the study were selected from threeintact classes consisting of 58 intermediate students studying English in Atiehsazan English Institute in Dehaghan, Isfahan, Iran. They were fifty two female students whose age ranged from 14 to 28 years. Their level of English proficiency was determined on the basis of their scores on the Nelson proficiency test. Each intact class was randomly selected to two experimental groups including (1) background knowledge questioning; (2) listening-while-reading; and onecontrol group. Because some of the students were absent during the implementation of one of the tests, they were excluded from the main subjects resulted in 17 , and 16 subjects in the respective experimental groups and 19 in the control group.

\section{B. Materials}

The following instruments were used for the purpose of this study:

\section{Language proficiency test (Nelson)}

This test comprised of 50 multiple-choice reading passage, vocabulary, and grammar sections. In order to test the reliability of the proficiency test, apilot study was carried out on 20 students. Its reliability through the K-R21 formula turned out to be .71, which was appropriate to take the next step.

\section{Reading passages for pretest and posttest}

The textbooks of English Reading Comprehension (Gupta, 2008) were adopted for this study. The topics of the passages are varied and the possibility of coming through something 'unhealed of before' is not remote. It covers some issues such as science, sports, ethics, education, religion, culture, health, technology, business, politics, entertainment, environment, etc. The selected texts for the purpose of this study were grade level reading materials selected to meet each group's instructional level and were linked to the reading and content learning objectives set by the selected subjects in this study. The texts opted for the present study were short, interesting, evocative, culturally relevant, and appealing to EFL readers at intermediate level. By considering the level of the participants, five listening passages, along with their multiple-choice questions, were selected. These passages were piloted for 10 students at the same class before doing the main study. By considering the results of the piloting, these passages were selected on the basis of potential interest and hypothesized unfamiliarity.Internal consistency reliability for the instrument was estimated by computing Cronbach's alpha coefficients. The overall test Cronbach's alpha was .70. This implies that the test has sufficient internal consistency in measuring the construct under investigation.In addition, as far as the validity of these topics is concerned, the files were sent to two EFL teachers, read them and judged the topics to be natural. The features of each passage were evaluated with respect to the number of words, the duration of topics, and the average word rate.Another criterion considered in this study for selecting the reading texts was the kind of strategywhich should be adopted by the students to respond to the questions in posttest stage. It should be mentioned that the texts implemented for pretest and posttest were the same.

\section{Instructional Design}

The strategy-based instructional approach selected for this research was the Cognitive Academic Language Learning Approach (CALLA), developed by Chamot and O'Malley (1994). The CALLA instructional model was designed to develop students' understanding of the value of reading strategies. In this study, it was utilized for the purpose of background knowledge activation strategy. The time spent on teaching this strategy was 90 minutes. As far as the procedure for practicing this strategy is concerned, before reading the text, students were instructed to determine the purpose of reading. They learned how the information in the text was organized. Before they started to read the main text, they were forced to read a short paragraph related to the main text in order to activate their background information or knowledge about the text they were going to read. They were also instructed to suggest some questions based on the short paragraph they read so that they could be able to find their answers after reading the main text. Altogether, encouraging students to generate questions about the text stimulate their background knowledge, to connect with the text, and to assess about what they had learned were the main purposes behind this strategy training.

\section{Procedure}

The present study was experimental in nature and therefore the researcher had to select her participants in a way they would be homogeneous in terms of language background. They were selected from among language learners in Atiehsazan English Institute. Students studying English at intermediate level from three intact classes were selected for the purpose of this study. They were fifty two female students whose age ranged from 14 to 28 years. First, they were given a Nelson Test as a placement test. Then they were classified into three groups, one control group and two experimental groups. 
After the subjects were classified into three groups, one control group and two experimental groups, all groups were given a reading comprehension test as a pretest. The scores obtained from this test were analyzed to see whether there is any difference between the three groups or not before intervention program.

\section{RESUltS AND DisCUSSION}

After data were collected, they were analyzed by using paired sample t-test and ANOVA in the following tables by considering the research questions.

Does activating background knowledge as a pre-reading task have any impact on EFL learners' reading comprehension performance?

In order to answer the first research question, data were analyzed and the following tables were elicited.

TABLE 1

MEAN PRE- AND POSTTEST OF B ACKGROUND KNOWLEDGE ACTIVATION SCORES FOR SAMPLES IN EXPERIMENTAL AND CONTROL GROUP

\begin{tabular}{|l|l|l|l|l|l|}
\hline Group & Test & Mean & N & SD & Std. Error Mean \\
\hline \multirow{2}{*}{$\begin{array}{l}\text { Background } \\
\text { Knowledge }\end{array}$} & Pretest & 13.06 & 17 & 2.410 & .585 \\
\cline { 2 - 7 } & Posttest & 17.06 & 17 & 2.076 & .503 \\
\hline \multirow{2}{*}{ Control } & Pretest & 12.32 & 19 & 2.626 & .602 \\
\cline { 2 - 6 } & Posttest & 12.37 & 19 & 2.712 & .622 \\
\hline
\end{tabular}

TABLE 2

PAIRED SAMPLE TEST FOR PRE- AND POSTTEST BACKGROUND KNOWLEDGE ACTIVATION AND CONTROL GROUP

\begin{tabular}{|l|l|l|l|l|l|l|l|}
\hline Group & Pair & Mean & SD & Std. Error Mean & T & Df & Sig (2-tailed) \\
\hline Background Knowledge & Pre- and posttest & -4.000 & 1.000 & .243 & -16.492 & 16 & .000 \\
\hline Control & Pre- and posttest & -.053 & 1.224 & .281 & -.188 & 18 & .853 \\
\hline
\end{tabular}

As it is evident from Table 2, there is no significant difference between pre- and posttest in control group in Iranian EFL context $(\mathrm{t}=.188 ; \mathrm{P}=.853)$ while with regard to the effect of activating background knowledge of learners about the topic they are going to read before reading a reading passage, results of data analysis ( $\mathrm{t}$-test) in table 2 above indicate that there is a statistically significant difference between students' performance in reading comprehension in pretest and posttest $(\mathrm{t}=16.492 ; \mathrm{p}<001)$. In other words, according to Table 1 , subjects scored higher in posttest $(\mathrm{M}=17.06, \mathrm{SD}=$ 2.076), when their background knowledge about the topic was activated before reading the main text, than pretest (without activating their background knowledge) $(\mathrm{M}=13.06, \mathrm{SD}=2.41)$. With respect to this point, the first hypothesis (Activating background knowledge as a pre-reading task can have an influence on Iranian EFL students' performance in reading comprehension) is accepted. In other words, activating background knowledge related to the topic play a significant role in developing the level of the learners' reading comprehension. It should be pointed out that this knowledge can be activated by asking some preview questions or reading a paragraph about the topic they are going to cope with during their reading comprehension.

This result can be regarded as a support for some other researches done in this area. For example, Pearson, Hansen, and Gordon (1979) demonstrated the importance of existing knowledge instudents' comprehension levels. The concluded that students receiving an $\mathrm{AO}$, which included related concepts found in a short story before they read the unfamiliar story, did better on a recall test than a control group, suggesting that indeed AOs improve reading comprehension(Rinehart et al., 1991; Rineheart\& Welker, 1992).

On the other hand, the result of the research done by Gutkind (2012) was against the result of this study. He investigated the schema strategy uses of fourth grade boys with reading challenges; specifically, their ability to understand text based on two components within schema theory: tuning and restructuring. The findings of this study indicated that the fourth graders with reading challenges displayed overall inefficient types of strategies when attempting to comprehend printed text, which was categorized as an inefficient comprehender.

Does listening-while-reading task have any impact on the learners' reading comprehension performance?

TABLE 3

MEAN PRE- AND POSTTEST OF LISTENING-WHILE-READING TASK SCORES FOR SAMPLES IN LISTENING-WHILE-READING AND CONTROL GROUP

\begin{tabular}{|l|l|l|l|l|l|}
\hline Group & Test & Mean & N & SD & Std. Error Mean \\
\hline \multirow{2}{*}{$\begin{array}{l}\text { Listening-while- } \\
\text { reading }\end{array}$} & Pretest & 12.81 & 16 & 2.834 & .708 \\
\cline { 2 - 6 } & Posttest & 14.56 & 16 & 2.828 & .707 \\
\hline \multirow{2}{*}{ Control } & Pretest & 12.32 & 19 & 2.626 & .602 \\
\cline { 2 - 6 } & Posttest & 12.37 & 19 & 2.712 & .622 \\
\hline
\end{tabular}

TABLE 4

PAIRED SAMPLE TEST FOR PRE- AND POSTTEST IN LISTENING-WHILE-READING AND CONTROL GROUP

\begin{tabular}{|l|l|l|l|l|l|l|l|}
\hline Group & Pair & Mean & SD & Std. Error Mean & T & df & Sig (2-tailed) \\
\hline Listening-while-reading & Pre- and posttest & -1.750 & 1.183 & .296 & -5.916 & 15 & .000 \\
\hline Control & Pre- and posttest & -.053 & 1.224 & .281 & -.188 & 18 & .853 \\
\hline
\end{tabular}

As it is evident from Table 4, there is no significant difference between pre- and posttest in control group in Iranian context ( $\mathrm{t}=.188 ; \mathrm{P}=.853)$ while with respect to using listening-while-reading task, it is clear from this table that students 
had a better performance in reading comprehension when the students were listening to the main textwhile reading (posttest) when it was compared to the results of students' performance during pre-test without listening while reading (pretest) (means 14.56 and 12.81respectively). According to table 4, the "t" value of 5.916 was found to be significant at .001level. Therefore, the second hypothesis (Listening-while-reading task cannot have an influence on Iranian EFL students' performance in reading comprehension) is rejected. In other words, listening to the main text while reading enhanced students' performance on reading comprehension.

The result of this research can be considered as a support to what Sticht and James (1984). They concluded from an analysis of 44 studies that the gap between the two skills gradually narrowed and agreed with Durrell that around the seventh or eighth grades the reading and listening abilities become similar. They also advised that reading instruction should include activities that bridge the gap between listening and reading. Miller and Smith (1990) did their research on silent reading, oral reading, and listening proficiency of poor, average, and good readers. They indicated some differences by ability level for listening and reading. For poor readers, they found that oral reading and listening comprehension was both superior to silent reading.

On the other hand, the result of this research question is against what Holmes and Allison (1985) did in their research. They showed that subjects in their study, 48 fifth-grade students, did not benefit from the listening-while-reading treatment. Furthermore, good readers seemed to be negatively affected by the listening-while-reading tasks.

Is there any significant difference between the effect of background knowledge activation task and listeningwhile-reading task on reading comprehension?

In order to answer the third research question, the collected data related to background knowledge activation group and listening-while-reading group were compared and analyzed as following:

TABLE 5

DESCRIPTIVE STATISTICS FOR BACKGROUND KNOWLEDGE ACTIVATION, AND LISTENING-WHILE-READING GROUP

\begin{tabular}{|l|l|l|l|l|l|l|}
\hline Group & N & Mean & Std. Deviation & Std. Error & Minimum & Maximum \\
\hline Background knowledge & 17 & 17.06 & 2.076 & .503 & 20 \\
\hline Listening-while-reading & 16 & 14.56 & 2.828 & .707 & 9 & 20 \\
\hline Total & 33 & 15.85 & 2.740 & .477 & 9 & 20 \\
\hline
\end{tabular}

TABLE 6

RESULTS OF ANOVA FOR MEAN POSTTEST SCORES OF SAMPLES IN BACKGROUND KNOWLEDGE ACTIVATION, AND LISTENING-WHILE-READING GROUP IN IRAN

\begin{tabular}{|l|l|l|l|l|l|}
\hline & Sum of Squares & Df & Mean Square & F & Sig. \\
\hline Between Groups & 51.364 & 1 & 51.364 & 8.430 & .007 \\
\hline Within Groups & 188.879 & 31 & 6.093 & & \\
\hline Total & 240.242 & 32 & & & \\
\hline
\end{tabular}

As it is evident in table 6, all the differences among the groups are significant between listening-while-reading and background knowledge activation group $(\mathrm{p}=.007<0.05)$. Therefore, there is a significant difference between the means of the two experimental groups. As a result, the third hypothesis (There is no significant difference between the effect of background knowledge activation task and listening-while-reading task on reading comprehension) is rejected. In other words, there is a significant difference between background knowledge activation strategy and listening-while-reading task in enhancing EFL learners' listening comprehension. In addition, by looking at Table 5 above, since the mean of the background knowledge activation is greater than that of the listening-while-reading group (17.06>14.56), we conclude that activating the students' background knowledge about the topic they are reading before reading main reading comprehension test can significantly better enhance the learners' reading comprehension than forcing students to listen while they are reading simultaneously.

By considering all of the above result, we can come to this conclusion that an important aspect of studying reading comprehension is to investigate both the products of comprehension and the processes as they are occurring. In this study, the products of comprehension indicated that activating prior knowledge and listening while reading as two effective tasks can increase the level of the learners' reading comprehension. In other words, the processes of comprehension were possibly changed, covering up the effects of background knowledge and listening-while-reading on the learners' reading comprehension in an EFL context.

\section{CONCLUSION AND RECOMMENDATIONS}

\section{A. Conclusion}

Supporting students as they read to learn is an important instructional goal throughout thecurriculum. Research studies have clearly established the importance of background knowledge to reading and understanding texts. Research studies also provide direct evidence that instructional strategies designed to support the accumulation and activation of prior knowledge can significantly improve student reading comprehension of informational texts. These studies suggest that by implementing instructional strategies to support students' background knowledge, teachers can better support students' content area learning. 
The best-supported approaches emerging from this review are direct instruction on backgroundknowledge, students' reflection on recording background knowledge, and activation of background knowledge through questioning. However there are other promising approaches, including the computer-supported approach CONTACT-2 (Biemans et al., 1996), which meritadditional research. The impact of such approaches on general literacy is another issue worthfurther study. Although a few studies support the effectiveness of background knowledgeinstruction for improving student comprehension of narrative texts, more research is needed.Another important conclusion that emerges from the research is the importance of consideringstudent characteristics, including their familiarity with a topic area and the accuracy of their prior knowledge.

Generally, Iranian EFL students have various obstacles to achieving proficiency in all of the language modalities: reading, writing, speaking, and listening. An unfamiliar script, a new sound system, and different cultural and social contexts all suggest a potentially bewildering array of new skills to be acquired. Among these skills, listening and reading comprehension is often allotted the least attention in the classroom. Generally, instruction focuses more on teaching grammar and vocabulary for the development of reading and writing skills. While it is important for students to become proficient readers and writers of English, the importance of strong listening and reading skills should not be understated.

In conclusion, the present study adds to the previous research regarding the importance of pre-reading activities. Prereading activities that activate EFL learners' content and formal background knowledge and require them to predict and interact with the reading passage enhance their reading comprehension performance. Finally, this study sheds some light on the importance of teaching EFL learners how to read, and focus on the reading process rather than the reading product. Such an approach to reading may reduce students' anxiety when carrying out a reading activity as they are not pressured to give correct answers, but rather, they engage in different activities which enhance their level of reading comprehension.

\section{B. Recommendations}

Research has shown (Anderson, 1994; Afflerbach, 1990; Rumelhart, 1984; Wade, 1990) that schema is an important element in reading comprehension. The current research has validated and expanded on the importance of schema, specifically schema strategyand its association with reading comprehension. Based on the results outlined in this research,the researcher suggested four important implications that relate to understanding and teaching adult learners how to comprehend printed text efficiently. First, this study validated the importance ofusing schema strategizing for successful comprehension of printed text. In addition, someevidence of inefficient strategy use was noted in all the participants in this study at the beginning of the study regardless of their reading comprehension levels, suggesting a need for teaching schemastrategizing. Metacognitive strategies, such as the use of schemaself-awareness, can be incorporated into the instructional methodology. Teachers ought toactively engage students in verbalizing their schemata, and discussing how their schematachanges to match new and incoming information from printed text.

The second implication of this study relates directly to curriculum and environment in theclassroom. Currently, curriculum programs do not address schema strategies as part of theinstructional learning process in reading comprehension. Most of the existing reading programshighlight the instruction of certain reading comprehension skills (i.e., main idea, inferences, drawing conclusions, etc.) but do not instruct on how to strategize these skills. It is evident, based on the results of this study that all students, regardless of their comprehension level, need to learn how to strategize in order tobecome successful and efficient comprehenders. Curriculum developers need to re-think theprocess of teaching reading comprehension by instituting daily practices in schema strategizingwithin the reading comprehension curriculum.

Third, there was some evidence of inefficient schema strategy use in all thevarious reading comprehension levels within each group. Therefore, teachers need to beresponsive to the diverse needs of the students' various reading comprehension levels byadjusting the classroom environment. Incorporating differentiated instruction with small andflexible grouping enables the teacher to reach all students, regardless of their academic level, bymaximizing their capacity to learn (Tomlinson, 2005).

Fourth, the results of this study also have implications for classroom teachers as they indicate that teachers need to pay more attention to helping students make connections between their existing knowledge and new material through introducing appropriate pre-reading activities. Teachers should also recognize that even though it might take them more time to prepare for pre-reading activities, the benefits gained from these activities may well merit the effort as the activities would improve learners' reading comprehension performance and thus contribute to enhancing their overall L2 language ability.

\section{REFERENCES}

[1] Afflerbach, P. P. (1990). The influence of prior knowledge on expert readers' main idea construction strategies. Reading Research Quarterly 25.1, 31-46.

[2] Anderson, R. C. (1994). Role of the reader's schema in comprehension, learning, and memory. In R. B. Ruddell, M. R. Ruddell, H. Singer, (eds.), Theoretical models and processes of reading (4th ed.). Newark, DE: International Reading Association, 469482. 
[3] Anderson, R. C. (1978). Schema-directed processes in language comprehension. In A. M. Lesgold, J. W. Pellegrino, S. D. Fokkema, \& R. Glaser (eds.), Cognitiv Psychology and Instruction. New York, NY: Plenum, 67-82.

[4] Anderson, R. C., Pichert, J. W., \& Shirey, L. L. (1983). Effects of the reader's schemata different points in time. Journal of Educational Psychology, 75(2), 271-279. http://content.ebscohost.com/pdf19_22/pdf/ddd/pdh/edu/edu-75-2271.pdf?T=P\&P=AN\&K=edu-75-2-271\&S=L\&D=pdh\&EbscoContent=dGJyMNHr7ESeqLc4yOvqOLCmr0qep7BSsau4S7e WxWXS\&ContentCustomer=dGJyMPGqs1C3qbJKuePfgeyx44Dt6fIA (accessed 18 /6/2012).

[5] Anderson, R. C., Reynolds, R. E., Schallert, D. L., \& Goetz, E. T. (1977). Framworks for comprehending discourse. American Educational Research Journal, 14(4), 367-381. http://aer.sagepub.com/content/14/4/367.full.pdf. (accessed 14 /6/2012).

[6] Anderson, R. C., Wang, Q., \& Gaffney, J. S. (2006). Comprehension research over the three decades. In A. K. D. Stahl, M. C. McKenna (eds.), Reading research at work; Foundations of effective practice. New York: Guilford Press, 275-283.

[7] Anderson, R.C., \& Pearson, P.D. (1984). A schema-theoretic view of basic processes in reading. In P.D. Pearson, R. Barr, M.L. Kamil, \& P. Mosenthal (Eds.), Handbook of reading research. White Plains, NY: Longman.

[8] Ausubel, D. P. (1977).The facilitation of meaningful verbal learning in the classroom. Educational Psychologist, 12, 162-178.

[9] Biemans, H.J.A. \& Simons, P.R., (1996). CONTACT-2: A computer-assisted instructional strategy for promoting conceptual change. Instructional Science, 24, 157-176.

[10] Bransford, J. D., \& Johnson, M. K. (1972). Contextual prerequisites for understanding: Some investigation of comprehension and recall. Journal of Verbal Learning and Verbal Behavior, 11, 717-726.

[11] Chamot, A. U., \& O'Malley, J. M. (1994).The CALLA Handbook: Implementing the Cognitive Academic Language Learning Approach. Addison-Wesley Pub. Co.

[12] Freebody, P., \& Anderson, R. C. (1983). Effects of vocabulary difficulty, text cohesion, and schema availability on reading comprehension. Reading Research Quarterly, 18, 277-294.

[13] Gutkind, R. C. (2012). The schema strategies in reading comprehension tasks of fourth-grade students with reading difficulties. Ph.D. dissertation, Fordham University. http://proquest.umi.com/pqdlink?Ver=1\&Exp=07-302017\&FMT=7\&DID=2595848041\&RQT=309\&attempt=1\&cfc=1 (accessed 29/5/2012).

[14] Holmes, B.C., \& Allison, R.W. (1985).The effect of four modes of reading on children's comprehension. Reading Research and Instruction, 25(1), 9-20.

[15] Horwitz, E.K. (1987). Surveying student beliefs about language learning.In A. Wenden\& J. Rubin (eds.), Learner strategies in language learning. Englewood Cliffs, NY: Prentice Hall, 119-129.

[16] Karbalaei, A. \& Rajyashree, K.S. (2009). The Impact of Summarization Strategy Training on University ESL Learners' Reading Comprehension. The International Journal of Language Society and Culture, 30, 41-53.

[17] Miller, S. D., \& Smith, D. E. (1990). Relations among oral reading, silent reading and listening comprehension of students at differing competency levels. Reading Research and Instruction, 29.1, 73-84.

[18] Oxford, R. (1990). Language learning strategies: what every teacher should know. Boston, Massachusetts: Heinle \& Heinle Publishers.

[19] Pearson, P. D., Hansen, J., \& Gordon, J. (1979).The effect of background knowledge on young children's comprehension of explicit and implicit information. Journal ofReading Behavior, 11, 201-209.

[20] Richards, J. C. (1996, summer). Teachers' maxims in language teaching. TESOL Quarterly, 30.2, 281-296.

[21] Rigney, J. W. (1978). Learning strategies: A theoretical perspective.In H. F. O’Neil, Jr. (Ed.), Learning Strategies. NY: Academic Press, 165-205.

[22] Rinehart, S. D., \& Welker, W. A. (1992). Effects of advance organizers on level and time of text recall. Journal of Reading, Research, and Instruction, 32, 77-86.

[23] Rinehart, S. D., Barksdale-Ladd, M. A., \& Welker, W. A. (1991). Effects of advance organizers on text recall by poor readers. Journal of Reading, Writing, and Learning Disabilities, 7, 321-335.

[24] Rumelhart, D. E. (1984) Schemata and the cognitive system. In R. S. Wyer \& T. K. Srull (eds.), Handbook of social cognition (vol. 1). Erlbaum, 161-88.

[25] Rumelhart, D. E. (1981). Schemata: the building blocks of cognition. In J. T. Guthrie(ed), Comprehension and Teaching: Research Reviews. Newark, DE: International Reading Association, 3-26.

[26] Song, M. (2011). Effects of background context and signaling on comprehension recall and cognitive load: The perspective of cognitive load theory. $\mathrm{PhD}$ dissertation, University of Nebraska. http://udini.proquest.com/view/effects-of-background-contextand-pqid:2434044731 (accessed 10/6/2012).

[27] Sticht, T.G. \& James, J.K. (1984). Listening and reading. In P. D. Pearson (ed.), Handbook of reading research. New York: Longman, 293-317.

[28] Tomlinson, C. A. (2005). Grading and differentiation: Paradox or good practice? Theory into Practice, 44(3), 262-269.

[29] Wade, S. (1990). Using Think-Alouds to Assess Comprehension. The Reading Teacher, 43, 442-451.

Rezvan Davaei received her MA in TEFL from Islamic Azad University, Shahreza Branch, Isfahan, Iran in 2012. She got her B.A in English Translation from Islamic Azad University, Shahreza Branch in 1999. She is active in teaching speaking, reading, and listening courses in atiyesazan institute in Dehaghan, Isfahan, Iran. She has presented 3 papers (two papers as posters in 2010 and one as a lecture in 2011) in research week conferences in Shahreza University. Her main research areas of interest are EFL teaching, second language acquisition, and discourse analysis.

Mohammad Reza Talebinezhad is an Associate Professor of Applied Linguistics at Islamic Azad University, Shahreza Branch. $\mathrm{He}$ is also an associate faculty member at Sheikhbahaee University, Iran. Dr Talebinejad received his BA in English Language and Literature, University of Isfahan in 1975. He then got his MA in TEFL from the University of Texas at Austin, USA in 1977. For his 
doctoral degree, Dr. Talebinejad was admitted to the University of Sheffield, UK, where he did his PhD in Applied Linguistics in 1994.

He has widely published in Iranian as well as International professional journals such as Metaphor and Symbol, English Teaching Forum, Language Testing, IJAl, Language and Translation, Journal of Social Sciences, The International Journal of Humanities, and other local and international journals. Dr Talebinejad has presented papers in International conferences such as AILA, 2000; Atiner, 2011; RAAM, 2002, 2001 in Paris and Tunis, EUROSLA, Switzerland, 2006; Multicultural Conference, 2007, China. In addition, Dr Talebinejad has authored/coauthored eight books in related fields and ESP. 